\title{
Beta Radiation Effect
}

National Cancer Institute

\section{Source}

National Cancer Institute. Beta Radiation Effect. NCI Thesaurus. Code C41569.

A Beta Radiation Effect involves biological damage caused by beta particles emitted from a radioactive source. Beta particle energy causes breakage of chemical bonds and ion formation in molecules, such as DNA and RNA, resulting in cell death or damage. 